POLITICS AND INTERNATIONAL RELATIONS

\title{
Foreign Policy Change in Latin America: Exploring a Middle-Range Concept
}

\author{
Federico Merke1, Diego Reynoso ${ }^{1}$ and Luis Leandro Schenoni ${ }^{2}$ \\ 1 Universidad de San Andres, AR \\ 2 University of Konstanz, DE \\ Corresponding author: Federico Merke (fmerke@udesa.edu.ar)
}

This article examines patterns of change and continuity in Latin American foreign policies. It asks two interrelated questions: How can we conceptually and empirically account for foreign policy change? And why do states change their foreign policies in Latin America? To answer these questions, we used the results of a new expert survey on foreign policy preferences in the region between 1980 and 2014. The results we obtained using both linear and nonparametric specifications are very clear and consistent: presidential ideology is what matters the most. Simply put, a change in the ideology of the president produces a change in foreign policy that is almost equivalent in magnitude, all other theoretically relevant factors set to their means.

En este artículo, examinamos los patrones de cambio y continuidad en las políticas exteriores de América Latina. Lo hacemos planteando dos preguntas relacionadas: ¿Cómo podemos dar cuenta conceptual y empíricamente del cambio en la política exterior? ¿Por qué los estados en América Latina cambian su política exterior? Para contestar estas preguntas, utilizamos los resultados de una nueva encuesta a expertos sobre las preferencias de política exterior entre 1980 y 2014. Los resultados obtenidos utilizando especificaciones lineales y no-paramétricas son claros y consistentes: la ideología presidencial es lo que más importa. Puesto de manera simple, un cambio en la ideología del presidente produce un cambio en la política exterior que es casi equivalente en su magnitud, ajustando todos los demás factores teóricamente relevantes a sus promedios.

\section{Introduction}

Foreign policy change has been, and continues to be, a common concern among Latin American scholars. Pundits and practitioners from different ideological persuasions often lament the abrupt changes in foreign policy and the lack of what they call a politica exterior de estado-the Spanish phrase for a stable, long-term, and consensual foreign policy. Foreign policy in Latin American countries has been alternately depicted as "erratic" (Gómez Mera 2009, 747), "inconsistent" (Margheritis 2010, 1), or merely "passive" (Tulchin 2016, 14). Yet Latin America is too complex a region to be captured by a single narrative. Compare Mexico's foreign policy, for instance, with Argentina's. While continuity and responsiveness to the international environment appear to be the dominant features of the former, fickleness and sensitivity to domestic whims have been a central trait of the latter. Countries like Brazil might be placed somewhere in the middle of the continuum, between Mexico and Argentina (Amorim Neto and Malamud 2015, 21).

Although foreign policy change is often depicted as a handicap, under certain conditions it can be an advantage. Foreign policies that adapt swiftly to changes in the international environment can benefit from this flexibility. It follows that in order to tell better-informed stories about Latin American foreign policy we need to be agnostic about the phenomenon and characterize it empirically before we can understand the drivers leading countries to different patterns of change and continuity. In the discussion that follows, we take a first step in that direction by asking two interrelated questions: How can we conceptually and empirically account for foreign policy change? And why do states change their foreign policies in Latin America? 
The first of these questions is particularly relevant since the conceptual tools to address foreign policy change have so far been elusive. Much of the foreign policy analysis (FPA) scholarship has focused on the set of different strategies by which a country relates to the world. This scholarship has examined the foreign policies of specific countries and produced overarching typologies. The result has been the proliferation of thickly descriptive, case-oriented studies that, given their level of complexity, seldom render generalizable explanations (Hey 1997; Mora and Hey 2003). A more recent scholarship, however, has introduced variableoriented studies more amenable to large-N statistical methods, aiming for greater generalization. Yet despite all its findings on a variety of issues, this approach has focused on single foreign policy issues or events (e.g., the signing of trade agreements, alliance formation, or voting patterns at the United Nations General Assembly UNGA), thus thwarting the evolution of foreign policy analysis toward higher levels of aggregation, that is, comparing foreign policies per se. In sum, FPA scholarship has been trapped between the qualitative analysis of broad foreign policies and quantitative explanatory designs addressing thin foreign policy issues. This deadlock calls for conceptual innovation and integrated methodological approaches (Goertz 2017).

Against this intellectual background interest has grown within foreign policy analysis in advancing a middle-ground approach (Alden and Aran 2017, 159) that can look at the evolution of foreign policy more broadly and in simplified terms that allow for meaningful comparisons in relatively large samples. In Latin America, this movement is still incipient (cf. Belem Lopes, Pimenta de Faria, and Santos 2016; Amorim Neto and Malamud 2015; Jenne, Schenoni, and Urdinez 2017). Most of the literature examining foreign policy change in Latin America focuses on few cases and emphasizes normative concerns. Scant academic effort has been put into developing rigorous comparisons in a relatively large-N context. Even more important, the existing literature has shown little interest, if any, in the development of middle-range concepts and theories. This kind of research, we argue, would be fitter for statistical analysis and could potentially lead to illuminating generalizations about the larger population of Latin American countries and beyond.

In this article, we examine patterns of change and continuity in Latin American foreign policies by defining a new middle-range concept: foreign policy change (FPCh). We believe that this concept retains our interest in the gross foreign policies of individual countries-that is, the aggregate of several foreign policies-while avoiding thick descriptions and identifying the relevant characteristics of that aggregate that we want to explain. In other words, FPCh does not fragment foreign policies in several parts but adds adjectives to the whole, for example, stable/unstable (Collier and Levitsky 1997; Goertz 2006). This approach, we argue, can be applied to many regions and epochs but can be especially suitable to create a more fruitful dialogue between foreign policy analysis and area studies, namely studying long-established Latin American foreign policy themes (e.g., trade policies, North/South interactions, or relations with the US) from a foreign policy analysis/international relations perspective. The outcome will not be a unified theory of foreign policy but a partial explanation to "provide insight into limited pieces of the overall puzzle of world politics" (Lake 2011, 467). In this case we focus on foreign policy change in Latin America.

To examine change and continuity in Latin American foreign policy, we used the results of a new expert survey on foreign policy preferences in the region between 1980 and 2014 (Merke and Reynoso 2016). This survey informed a database of 142 administrations and their respective orientations on three policy domains: pro/anti US positioning; North-South orientation of political partnerships; and place in the liberalprotectionist continuum. We do not look at FPCh as the binary opposite of continuity. We rather aim to examine varying degrees of change and continuity across time and space.

\section{Explaining Foreign Policy Change in Latin America: An Institutionalist Approach}

Why does foreign policy change? One of the striking lacunae in the study of foreign policy is the paucity of empirical analyses on the causes of change. In a thorough review of the literature, Gustavsson (1999, 87) observed that "there are relatively few" empirical studies on foreign policy change, and Garrison $(2006,291)$ then agreed to say that change received "only sporadic attention" in the foreign policy analysis literature. More recently, Blavoukos and Bourantonis $(2014,483)$ stated that foreign policy analysis tended to focus "on continuity and stability" with only "sporadic attempts to account for change," and Alden and Aran $(2017,12)$ concluded that change "is a neglected aspect of the study of foreign policy."

Although a comprehensive review of foreign policy change is beyond the scope of this article, we observe four salient features of the study of change. First, research on foreign policy change is inherently interdisciplinary. For this reason it can be a site of intersection between different, related fields, for example, political science, international relations, comparative politics, and political psychology (Alden and Aran 2017, 134). In this article, we are particularly interested in observing how domestic political changes interact with global shifts to yield different foreign policy outcomes along the stability-instability spectrum. 
Second, and relatedly, the study of change has been and continues to be a multicausal enterprise. Why do states behave as they do in world politics? Foreign policy analysis scholarship gives no simple answer to this question, and the literature has relied on international and domestic parameters, material and ideational drivers, and human agents and structural constraints. As a result, there is no single, unified theory of change nor even a limited yet consistent set of variables to explain shifting behaviors. Explanations range from the interplay of structure and agency (Skidmore 1994; Goldmann 1988) to cyclical models (Carlsnaes 1992; Rosati 1994) and to cognitive biases (Welch 2005).

Third, FPA scholarship in Latin America has been no exception to these lacunae. Undoubtedly, the literature exhibits a large scholarly production that examines, for example, the change of foreign policy in Argentina, Brazil, or Venezuela. But efforts to theorize these changes beyond a particular country have been rather scarce. As a result, we now have good stories to tell about individual foreign policies but we are still a long way from establishing generalizable observations.

Fourth, the literature on change has notably overlooked the impact of domestic institutional variables, particularly the structure and role of the executives. As Alden and Aran $(2017,13)$ note, "FPA says little about the sources and conditions giving rise to significant alterations in a state's foreign policy." "Understanding and integrating 'change' into analyses of foreign policy," they affirm, "requires accounting for its impact in relation to individual decision makers, institutions and structures of decision making as well as the wider socio-political and external context within which such change occurs" (Alden and Aran 2017, 14). In this article, we take this observation seriously by studying the executive and its institutional context while controlling for other domestic and international variables.

\section{The Presidency and Its Institutional Context}

Alden and Aran $(2017,138)$ claim that the study of FPCh "through the three prisms of the individual, state institutions and political regimes, provides some of the foundational pillars required for the development of a theory of foreign policy change." Given that foreign policy is preeminently in the hands of the executive power, we follow these authors' advice and focus on how presidential preferences are constrained by the institutions of the executive power in democracies.

A large body of literature has argued that the executive is the main actor in foreign policy decisionmaking and therefore should be the central focus of any theory of foreign policy change. According to Milner and Tingley $(2016,263)$ this literature highlights that the executive "negotiates and interacts with foreign leaders"; is the main point of "governmental contact with foreign governments"; "transmits the international environment into the domestic process of policy making"; and "his perceptions and views on what the international environment is like tend to dominate the domestic policy process." Thus, a narrow focus on the executive seems to be the natural starting point for any theory of foreign policy change.

This observation holds particularly for Latin America. As Mora and Hey $(2003,4)$ observe, Latin American foreign policy "has traditionally been the preserve of the executive and a narrow elite." Typically, presidents have enjoyed a wide margin of maneuver to conduct foreign affairs, and thus much of Latin American foreign policy can be explained by studying presidential preferences (Malamud 2014; Jenne, Schenoni, and Urdinez 2017; see also Burges and Chagas Bastos 2017).

Recent research suggests that this trend has only grown over the last twenty years. Malamud $(2005,158)$ examined presidential intervention in the management of Mercosur to conclude that presidents exhibited a significant degree of autonomy, "acting not only as decision makers but also as dispute settlers and guarantors of commitments." For Malamud (2015), president-to-president interactions in Latin America can be understood as a dominant type of diplomacy, namely "inter-presidentialism." Emerson $(2015,488)$ explored the growing importance of the executive to the foreign policies of Brazil and Venezuela and concluded that the "presidentialization" of foreign affairs has led to a "short-term focus aligned with the electoral cycle, and a greater degree of personalism." In sum, research on Latin America foreign policy suggests that the study of presidential preferences can illuminate important aspects of foreign policy change. In what follows, we introduce alternative hypotheses that flow from this reasoning.

This is not to say, however, that presidential preferences have been uncontested domestically (by the military, the opposition, or the private sector) or that presidents have been immune to international constraints. We argue instead that presidents typically have enjoyed a wide margin of maneuver to conduct foreign affairs, and thus much of Latin American foreign policy can be explained by studying presidential preferences and constraints. If presidents are driving foreign policy, then a first observational implication of our theory is that a change in the president's preferences will be associated with a change in foreign policy.

Yet presidential democracy in Latin America exhibits various political models. Comparative political scientists have examined the relative strength of presidents, finding variation within the region. Following 
insights from the rational-choice literature on veto players (Tsebelis 2002), some have already interpreted foreign policy change as caused by the concentration of power in the president (Lima and Santos 2001; Schenoni and Aztiria 2014); thus we have reasons to believe that presidential systems that show higher levels of power concentration in the chief of state are intrinsically more prone to policy change. In other words, more presidential power will lead to more change in foreign policy.

Although institutional characteristics of presidential power are relatively constant, presidential independence from political actors and institutional constraints can vary over time in the same political system, leading to different degrees of foreign policy change. A radical form of this phenomenon occurs when presidents are in overt conflict with other powers and therefore insulated from those political influences during presidential crises (Pérez-Liñán 2007; Llanos and Marsteintredet 2010). Previous research has shown that attention to international incentives is reduced in contexts when presidential mandates are at stake (Schenoni 2017), and it is equally plausible that foreign policies will be disturbed through similar mechanisms. We thus expect that presidential crises will be associated with foreign policy change.

Finally, presidents can face very different bureaucracies constraining them. In the Latin American context, for instance, the Brazilian Ministry of Foreign Affairs is widely known for its bureaucratic powers, esprit de corps, and outstanding training (Da Faria, Lopes, and Casarões 2013). Brazilian diplomats are highly influential in the foreign policy circle, and foreign ministers themselves often come from their ranks. Other bureaucracies are not as professional or as influential. Some countries do not even have a particular institute to form their future diplomats. In many such countries ambassadorships are granted to politicians with no credentials. More generally, executive bureaucracies beyond the diplomatic corps can strongly constrain presidents in key foreign policy agendas such as trade, defense, finance, environment, or migration. This can be due to the influence of their standard operative procedures, bureaucratic cultures, and even their political power (Allison and Zelikow 1999). In any case, they should act as stabilizers (Goldmann 1988; Skidmore 1994). This leads to a clear prediction: weaker executive bureaucracies will lead to higher foreign policy change. ${ }^{1}$

In sum, our model predicts that a change in the incumbent's preferences-for example, a change in presidential preferences-will ceteris paribus result in FPCh. They also predict that institutions that strengthen the president or critical junctures where the president is particularly isolated from other powers will increase FPCh. These were the conditions, for instance, under which the government of Carlos Menem brought about a radical turn in Argentina's foreign policy toward the United States or Fernando Collor de Melo abandoned a third world perspective in Brazil's foreign policy. Conversely, we expect that institutions constraining the power of the president, such as strong executive bureaucracies, will have a stabilizing effect and thus will lead to change in foreign policy. This has been the case in Chile since the transition to democracy in 1989, where socialists, Christian democrats, and right-wing presidents, albeit with differences, have converged on the fundamentals of Chile's foreign policy.

\section{Measuring Foreign Policy Change in Latin America: Themes, Data, and Patterns}

To unpack the range of variability in FPCh it is helpful to focus first on the key dimensions of Latin American foreign policy. Though the task of explaining Latin American foreign policy goes beyond the scope of this article, this section aims to flesh out the essential contours of Latin American foreign policy and then estimate variation within and between countries. Some themes emerge throughout the literature (Hey 1997; Giacalone 2012). We present here three dimensions of foreign policy that we believe capture some important and enduring dilemmas in the region. Undoubtedly the three dimensions are empirically connected, yet they are analytically distinguishable.

First, the study of Latin American foreign policy has been particularly concerned "with the United States and the degree to which its activities and policies constrain Latin America's foreign policy aspirations and behavior" (Mora and Hey 2003, 4). Indeed, the literature on US-Latin America relations is comparatively the largest (Giacalone 2012). The dynamics between Latin America and the US are deep and broad, spanning issues from security to finance and trade and involving myriad actors (Carothers 1993; Kryzanek 1990; Schoultz 1998; Atkins 1999; Pastor 2001; Rivarola Puntigliano 2008; Smith 2000;Weeks 2009; Pastor and Long 2010; Williams 2011; Bertucci 2013) with diversified foreign policy standpoints (Russell and Tokatlian 2008). Both dependency theorists and realists highlighted the asymmetrical power relations that pervade

\footnotetext{
${ }^{1}$ We would like to thank one reviewer of LARR for pushing us to incorporate this element. As it will become evident in the final analysis, this seems to be a variable of considerable importance.
} 
the western hemisphere and asked to what extent Latin America dependence was reflected or not in its "foreign policy under asymmetry" (Long 2015).

Second, another recurrent theme in Latin America has been its place in the North-South divide and the discussion over the benefits that can be obtained from an alliance with industrialized/developed countries vis-à-vis the developing world (Puig 1980; Jaguaribe 1985; Escudé 1992; Hey 1997; Russell and Tokatlian 2003; Briceño Ruiz 2012; Schenoni and Escudé 2016). Those countries that emphasized NorthSouth relations sought to engage politically and economically with the Western industrialized countries seeking to attract investment, increase foreign trade, and obtain varying degrees of political support and military aid. Alberto Fujimori in Peru, Carlos Menem in Argentina, Fernando Collor de Mello in Brazil, and Carlos Salinas de Gortari in Mexico are some examples of this pro-North policy. Those who emphasized South-South cooperation, in contrast, advocated third world solidarity and sought to strengthen political sovereignty, increase the margin of autonomy, and restrict external intervention in domestic affairs by Western powers and international organizations. Fidel Castro in Cuba, Hugo Chavez in Venezuela, Evo Morales in Bolivia, and Rafael Correa in Ecuador headed frequently in this direction. We suggest, however, that this has not been a merely binary opposition and that one can find different degrees of policy along the North-South spectrum. Raúl Alfonsín in Argentina, Fernando Henrique Cardoso in Brazil, and Tabaré Vázquez in Uruguay are some examples that illustrate our observation. It follows that "pure" versions of pro-North or pro-South postures should be seen as extremes of a continuum that in practice has been more complex.

Third, there is the political economy of foreign policy. The literature examining this dimension focuses on several issues including the political and commercial relationship with the United States (Bergsten 2002; Feinberg 2002); the role given to transnational corporations; the relationship with the global flow of capital (Robinson 2008); and the positions adopted vis-à-vis global and regional trade (Bouzas 2000; Phillips 2003, 2014; Tussie 2009). In these debates, trade policy has been a fundamental instrument used to address Latin America's regional and global economic integration. Yet the region exhibits recurring discussion of the benefits and desirability of international trade integration. Supporters of free trade argue that an open economy expands national wealth by lowering the price of goods, amplifying growth, and promoting innovation and investment, among other things. Globalization skeptics, on the other hand, have argued that open trade increases job outsourcing, makes income distribution more unequal, establishes poorer working conditions, and leads to depletion of natural resources by transnational corporations. As with the previous themes, we understand this debate as a continuum rather a binary opposition between open and closed trade.

We want to know how foreign policy changes along these three dimensions from one administration to another, and the degrees of change and continuity between countries over the same period of time. Compare Menem in Argentina (1989-1999) with Cristina Fernández de Kirchner (2007-2015). While Menem was a pro-US, pro-North president and advanced neoliberal reforms to open up the country to globalization, Cristina Kirchner exhibited a more anti-US orientation; her diplomacy enhanced a SouthSouth standpoint and kept Argentina under more restrictive trade arrangements. Though by no means a comprehensive analysis, we believe these dimensions do serve to capture fundamental patterns of change and continuity in Latin America's foreign policy.

In order to examine preferences regarding foreign policy, we asked a total of 134 experts in nineteen Latin American countries to locate administrations in their own countries from 1980 to 2014 in the three dimensions outlined above on a seven-point scale. Expert survey is an extensively used method to locate agents (e.g., parties, governments, or presidents) in a given policy space (Budge 2000). Yet it has often been disqualified for reflecting subjective biases and conceptual inconsistencies among experts (Bollen and Paxton 2000). When it is done following certain rules, however, it can help to provide more accurate estimates. To avoid pitfalls and enhance the production of genuine expertise, Schedler (2012) recommends, among other things, working with a consistent selection of experts; an elaborate conceptual disaggregation; and an additive procedure (e.g., arithmetic means). We took his recommendations seriously by identifying foreign policy experts and not country experts. We also asked them to estimate each president not on a single foreign policy dimension but on several (e.g., ideology, the US, geopolitics, and trade). And we added up different individual estimates so to have a single arithmetic means for each president. In sum, expert survey helps to quantify actor positions and bring flexibility about different dimensions being asked.

Working with the expert survey, we built a database of 142 presidents and their external orientations on three dimensions: positioning toward the US (from bandwagon to autonomy); orientation toward international society (from pro-North to pro-South); and positioning toward trade (from open to closed). 
As we argued above, these three dimensions are related to each other. We expect that administrations that favor trade openness also pursue close relations with the US and with countries in the North.

On these findings, we used dynamic component analysis to aggregate the three dimensions (see online appendix 2). This technique transforms our variables into a principal component that accounts for much of the variability among them (Abdi and Williams 2010). Our index resulted in scores between 0 and 1 , where 1 represents a latent "liberal" aspect of foreign policy that is characterized by orientation to the North, the US, and free trade. This composite index provides two important advantages. First, it allows measuring the broader concept of foreign policy instead of different particular dimensions. Second, principal component analysis weighs the components not subjectively but on the basis of the underlying correlation among them. Therefore, this index results in a better indicator of the orientation of Latin American foreign policy than any of the dimensions taken alone.

Once we have captured fundamental foreign policy orientations-our middle-range observations of interest-the next logical step is to measure FPCh, which we understand as the level of variation in foreign policy from one presidential term to the next. The data transformation that we propose is relatively straightforward:

$$
F P C h=\sqrt{\left(F P_{t}-F P_{t-1}\right)^{2}}
$$

As defined above, for every country, FPCh results from a change $\triangle F P$ which we then square and take the square root of because we are not interested in the relative direction of such change but in the absolute value of change. In other words, we do not care whether the Latin American president had a more or less liberal foreign policy. Instead, we focus on whether FPCh-no matter the direction-was more or less abrupt. Online appendix 1 shows the figures of FPCh for the nineteen Latin American countries in our sample.

Figure 1 shows the standard deviation of the aggregate Latin American foreign policies. Given our definition of FPCh, this is equal to the average FPCh for each country in the period 1980-2014 and has an upper bound of 1 .

As one would expect, Cuba is the country that altered its foreign policy the least between administrations. This may be understood in relation to the stability of its political regime. Since 1959, Fidel Castro's leadership style and ideology "have defined the nature of the regime and its foreign policy" (Fernández 2003, 98). For all its continuity, however, Cuba also faced the need to make important adjustments, as seen in Figure 2. Close to Cuba is Panama. The literature (Sanchez 2003) identifies its stability as a function of two simultaneous events: the end of the Cold War, when Panama ceased being a chess piece in US grand strategies, and the transition to democracy, when Panama adopted most of the Washington Consensus recommendations. Chile is another case in point. Fernandois $(2011,50)$ depicts Chile as a country that despite global and domestic

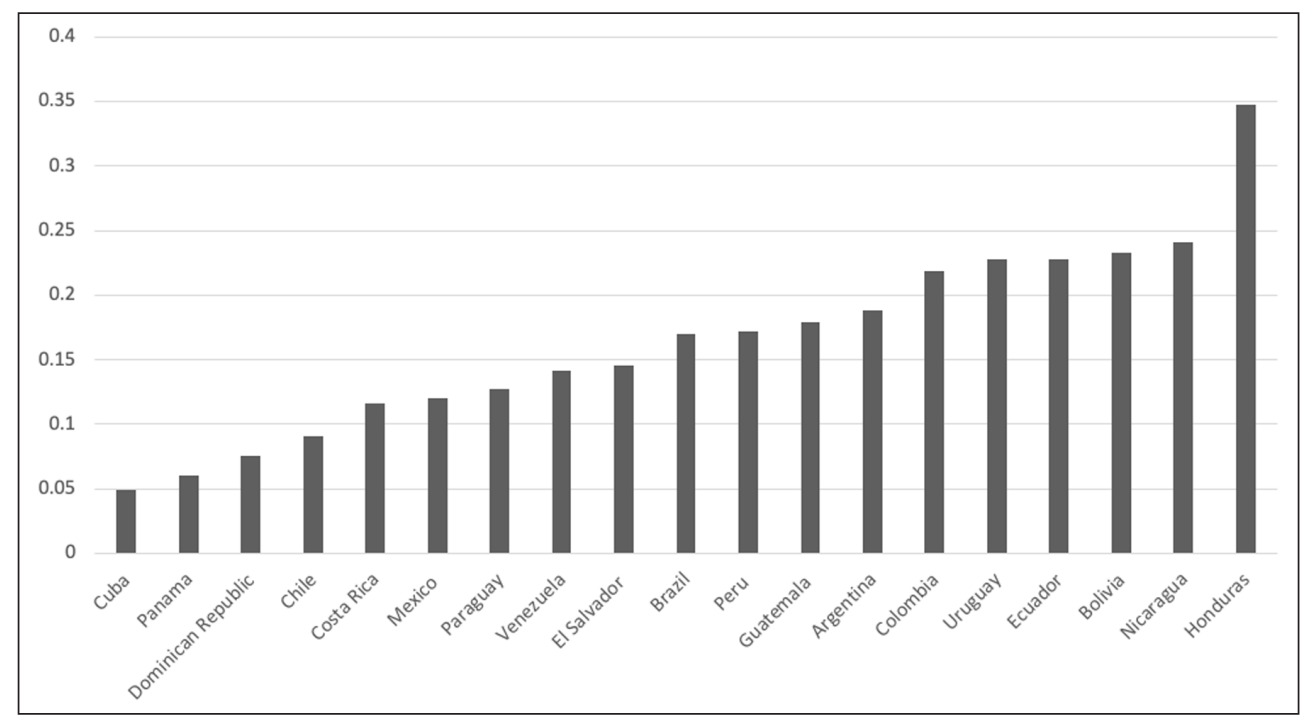

Figure 1: Foreign policy change in Latin American countries (average). (Based on data from Merke and Reynoso 2016). 


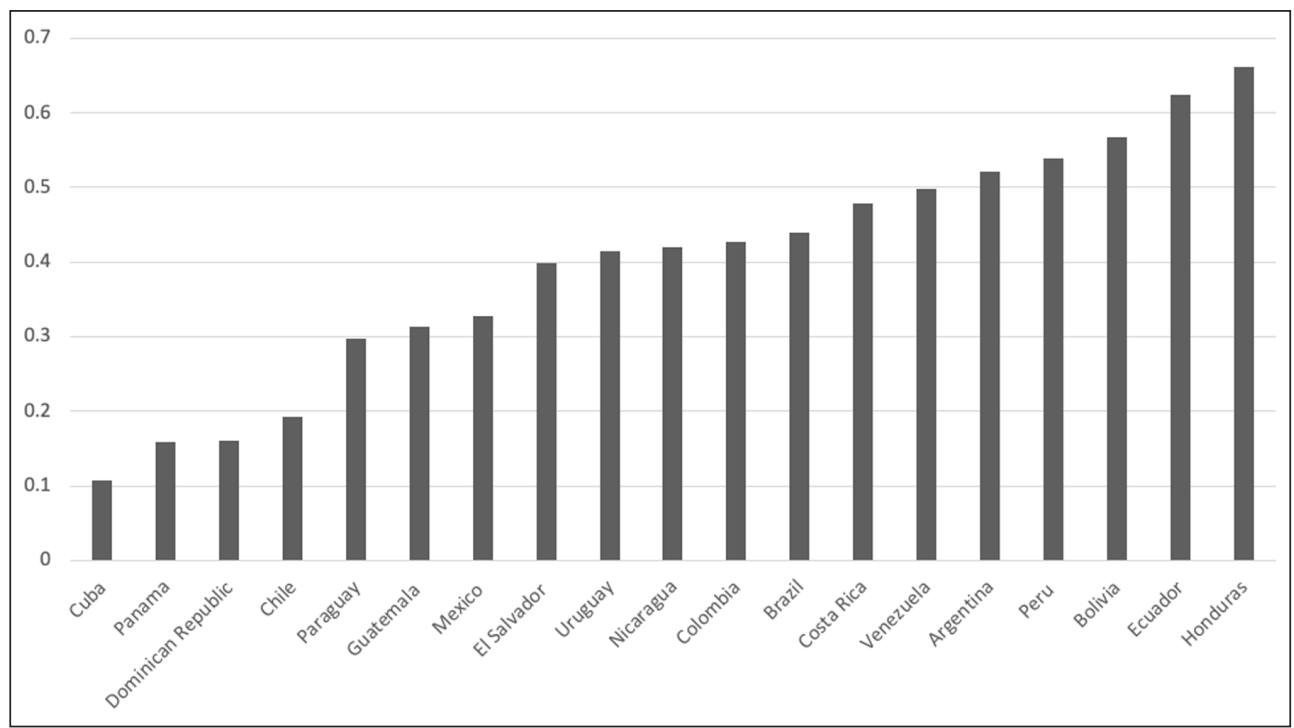

Figure 2: Foreign policy change in Latin American countries (highest value in the series). (Based on data from Merke and Reynoso 2016).

changes has "remained surprisingly faithful to a longer commitment to an ideology of legality, development and pragmatism."

At the end of the instability spectrum, it is observed that, on average, a change of administration in Honduras yielded 0.35 points of change, which is strongly related to the swing of the pendulum, amid crises, between the Honduran National Party and the Liberal Party of Honduras. Similarly, Nicaragua's instability seems to be also correlated with the ideological cleavages between the radical left Sandinistas and the freemarket, pro-America right parties such as the National Union of the Opposition or the Constitutional Liberal Party (Close 2011). This is also the case of Bolivia, where "chronic instability," together with other constraints, has inhibited a more consistent foreign policy (Morales 2003, 228).

Figure 2 adds more information showing the maximum values of change between two consecutive administrations. Honduras continues to be located at the end of the spectrum, with a turnaround of almost 0.7 (from a possible maximum of 1). This abrupt turn took place in 2006 between the administrations of Ricardo Maduro Joest and José Manuel Zelaya Rosales. Another important turn was given by Ecuador in 2007, when Rafael Correa took over after the administration of Alfredo Palacio González. Similar changes, albeit in different directions, took place in Bolivia in 2006 with Evo Morales, Peru in 1990 with Alberto Fujimori, and Argentina in 1989 with Carlos Menem. Interestingly, Brazil occupies an intermediate position along the spectrum of change. Brazil has typically been seen as the role model of a consistent foreign policy based on legitimate principles such as universalism, autonomy, and development. Yet behind this narrative, Brazil exhibits important changes amid continuities (Amorim Neto 2012).

So far, we have introduced an empirical operationalization of foreign policy in Latin America and defined what we mean by change. The result is a first estimate of FPCh in the region, of which we offer brief descriptive statistics in Figures $\mathbf{1}$ and 2. This description allows us to conclude a few things about FPCh in Latin America. In particular, these statistics unveil a clear hierarchy between countries. While Panama, Dominican Republic, Chile, Cuba, and Costa Rica exhibit significant levels of continuity between administrations, Honduras, Ecuador, Bolivia, and Argentina tend to show higher levels of change. Hence, the labels of "inconsistent" or "erratic" foreign policies that are uniformly granted to these countries by the press, when studied from an academic perspective, should consider this relative order.

In the following section, we will briefly examine the performance of our theoretical expectations based on the characteristics of the executive power, together with other domestic and international factors that may possibly account for these diverse patterns. Although the stable hierarchies depicted in this section suggest long-term factors might be determining the stability of foreign policy (and perhaps the stability of policy, more broadly) in a path-dependent manner (Mahoney 2010; Soifer 2015), we will focus mostly on factors that have varied in the 1980-2014 period and use fixed effects in our models to control for those timevarying features. Our quantitative approach, however, does not preclude the possibility that historical events previous to 1980 might have set these countries in their current course of relative foreign policy stability-a possibility that further research could scrutinize. 


\section{Hypotheses: Presidential and Alternative Explanations}

Recapitulating, our model of FPCh bases its predictions on the characteristics of the executive. More precisely, it predicts that changes in executive-in the Latin American context, presidential-preferences, power, and institutional environment would be the best predictors of FPCh. We use a set of four indicators to capture our president-related hypotheses of interest.

\section{Presidential Variables}

The first and most clear prediction of our theory is straightforward:

H1: A change in the president's preferences will be associated with FPCh.

To estimate the aggregated preferences of each president, we rely on data measuring presidential ideology from Merke and Reynoso (2016). Ideology is measured in a seven-point scale, where 1 is left and 7 is right, and change is measured in the same way we described above. Yet presidents also vary in their power, so we expect:

H2: With greater presidential power, there will be more change in foreign policy.

We use Shugart and Carey's index of presidential powers (1945-2005) retrieved from Mainwaring and Perez-Liñan (2013). This index reflects the sum of two point-score measures: an index of legislative powers, reflecting proactive and reactive powers vis-à-vis the legislature, and an index of nonlegislative powers, reflecting presidential control over appointments and over the dissolution of congress. These institutions, however, capture presidential power de jure but fail to capture the ebb and flow of de facto presidential influence. To compensate for that we also predict:

\section{H3: Presidential crises will be associated with FPCh.}

We use here a simple dichotomous indicator adopting the value of one (1) if the administration was preceded by an episode of presidential crisis (Pérez-Liñán 2007). Finally, very strong presidents, both institutionally and factually, could be relatively weakened by the presence of strong executive bureaucracies, and thus we propose:

H4: Weak bureaucracies will be associated with FPCh.

Since there are no available indicators of the relative strength of the diplomatic bureaucracy, we proxy this by using the Varieties of Democracy (V-Dem) public sector corruption index. The indicator captures to what extent public sectors officials act in a meritocratic fashion and according to bureaucratic rules or grant positions and benefits in exchange for personal economic or political gain (Varieties of Democracy Project 2017). This indicator has significant face validity, with countries known for their strong state capacity and diplomatic corps such as Brazil, Chile, Costa Rica, and Uruguay at the top of the rank.

\section{Partisan and Regime Variables}

In an alternative explanation, FPCh could reflect a change in the president's constituency (Bueno de Mesquita et al. 2003) instead of a change in presidential preferences. FPA scholars have recently developed measures of change in the source of leadership support to test for the impact of coalitional change independently from presidential ideology (Mattes, Leeds, and Matsumura 2016). ${ }^{2}$ To disentangle whether FPCh is due to the change in presidential preferences or those of the president's coalition, we consider the possibility that a change in the ideology of the party of the president explains FPCh.

H5: Changes in the incumbent party's ideology will be associated with FPCh.

To measure incumbent party ideology we use data provided by Murillo, Oliveros, and Vaishnav (2011) that locates parties in government in a five-point scale. Another factor that may affect the stability of a foreign

\footnotetext{
${ }^{2}$ Unfortunately, those measures do not cover our entire time span. Yet, we believe our control for presidential party ideology gets closer to the preferences of the president's coalition in most Latin American countries.
} 
policy is the abrupt change in the vote share of political parties that compete in elections. In line with our argument about coalitions, the rise of new parties or the collapse of old, standing organizations could affect the political consensus, causing the volatility of all types of policy (Mainwaring 2017) including foreign policy (cf. Schenoni 2017).

H6: Higher electoral volatility will be associated with higher FPCh.

We use scores of electoral volatility in the elections for the lower chamber during the year that the president was elected (if presidential and legislative elections were concurrent) or those of the first legislative election after the president was elected. Data was retrieved from Mainwaring (2017).

Hypotheses $\mathrm{H} 2$ and $\mathrm{H} 3$ can only take place if the countries are democracies or very sophisticated, institutionalized authoritarian governments. Also, by examining Figures $\mathbf{1}$ and $\mathbf{2}$ above, one could surmise that autocracies are less prone to change than democracies due to the relative stability of those in power. Cuba, with the lowest average FPCh in the region, is a case in point. Thus, a control for regime type is required.

H7: The greater the level of democracy, the higher the FPCh.

Drawing on the Freedom Index, we follow the recodification used in Mainwaring and Pérez-Liñán (2013), in which scores are recoded to range between 0 and 12 , where 12 is most democratic. The observations represent the mean Freedom Index score during a given presidency.

As a final domestic variable of interest we consider the possibility that extreme polarization or radicalization might be leading to FPCh, as different political actors might be stuck in centrifugal dynamics that lead them to support extremely different foreign policies.

H8: The greater the levels of radicalization, the higher the FPCh.

We use Mainwaring and Pérez-Liñán's (2013) measures of radicalism in all government and opposition political actors. This indicator varies between low (0) and high (1) levels of radicalization.

\section{System-Level Variables}

As we argued above, the international factors that can provoke change in a given foreign policy are many, ranging from the coercion of a hostile third state to smooth adaptation to evolving international norms or regimes. In Latin America, however, the literature seems to agree that changes in foreign policy are attributable to a narrow set of international issues, namely the international economic environment (e.g., the so-called commodity boom), the varying influence of Washington (from the Monroe Doctrine to Roosevelt's Big Stick to the Washington Consensus) and the shock of crucial global changes (e.g., the end of the Cold War or the beginning of the global war on terror).

International factors can take the form of single events or critical junctures affecting the foreign orientation of several countries at the same time. In this light, almost nobody disputes that the end of the Cold War had a profound impact on the pattern of international relations. One could expect, for instance, that the end of the Cold War resulted in incentives for Latin American countries to realign with the US because of a new distribution of power in which the US remained as the sole superpower. Therefore:

H9: The end of the Cold War will lead to a change in foreign policy.

We use here a simple dichotomous indicator, which adopts the value of one (1) if the dissolution of the Soviet Union took place during the presidency.

In the same way, the 9/11 attacks on the World Trade Center had enormous strategic consequences for the US and international society. They changed conventional attitudes toward terrorism dramatically and irrevocably. And they changed US foreign policy as the US declared a global war on terror. Did 9/11 alter Latin American foreign policies? Gardini and Lambert $(2011,5)$ argue that "Latin America is a region where the impact of 9/11 and the so-called War on Terror has been less strongly felt." Yet there is no empirical analysis of this observation covering the whole region or at least the most significant states thereof. The hypothesis, therefore, is as follows:

H10: The 9/11 attacks will provoke a change in foreign policy. 
As with H9, we use here a simple dichotomous indicator, which adopts the value of one (1) if 9/11 occurred during the presidency.

Economic growth is another variable of interest for our analysis. Both cyclical (Carlsnaes 1992; Rosati 1994) and loss-aversion (Welch 2005) models expect FPCh to occur when the economy is doing badly. An important body of literature has been devoted to explore how economic constraints provoked the realignment of Latin American countries' foreign policies as a way to access credit, investment, and even aid (Feinberg 2002; Phillips 2004; Grugel and Riggirozzi 2012). The implicit understanding of this literature is that countries in dire straits have to make substantial changes in their foreign policies if they want to get help from the markets or a more powerful country. For Latin Americans, this may evoke recurrent debates about how to "return" to world politics-"la reinsersión del país en el mundo"-that used to follow long periods of retraction or isolation. In this light, Latin American foreign policy has its own flavor, say Mora and Hey $(2003,9)$, and it is "peppered by the role of core actors and domestic economic crisis." Conversely, countries that do well economically would not have a reason for changing their current foreign policy course. This literature has specific observational implications that we try to test in this article:

\section{H11: Lower economic growth will lead to higher FPCh.}

To examine economic growth, we will look at growth in per capita GDP. We use the World Bank's World Development Indicators for the first year of the presidency.

Alternatively, some have argued that FPCh is a function of US influence over Latin American countries and the extent to which these countries have enough leverage to resist the mandates of Washington. Applying this argument to the democratization debate, Levitsky and Way (2010) have recently proposed that the probability that a given country will evolve toward a competitive authoritarian regime is a function of the linkages and leverage that the US has vis-à-vis that particular country. In general, one could argue that the regional hegemony of the US might be a potent stabilizing factor (Mearsheimer 2001). The analogy with FPCh is thus all too straightforward:

H12: The higher the US influence, the lower the FPCh.

To estimate US influence in the region we use trade data provided by Barbieri, Keshk, and Pollins (2009). We compute total trade as the sum of exports and imports to the US and then divide it by population to get a per capita specification that controls for country size.

Lastly, Urdinez and colleagues (2016) find that Chinese influence has acted as a countervailing force to US influence in Latin America, at least since 2003. Their article was followed by literature confirming that China might have stirred some foreign policies away from their normal course, which leads to our final alternative hypothesis:

H13: The higher China's influence, the lower the FPCh.

We measure the influence of Beijing in the same way we did that of Washington.

\section{Statistical Model}

Given the structure of our data and the distribution of our dependent variable (FPCh) we use two main statistical frameworks to test the aforementioned hypotheses. We start with a standard linear approach, that is, a simple ordinary least squares (OLS) model with autocorrelation and cluster correction, robust standard errors, and country fixed effects. Since we are exploring a measure of change, autocorrelation in these models is theoretically and empirically of little relevance, which we corroborate by including a lagged specification of FPCh in robustness checks. This linear specification provides a correct (Beck and Katz 1995) yet probably too parsimonious heuristic. This is so particularly because of the characteristics of our dependent variable.

In a second approach, we take two characteristics of FPCh more seriously: that our index is bounded between 0 and 1 , and that it is continuous between the two, with a distribution that is skewed toward zero and with almost no observations beyond a 0.6 threshold. This distribution suggests that a specific type of generalized least square (GLS) model is necessary and a logit or probit specification might not be particularly suitable. The type of model that better fits this distribution is a beta regression (Ferrari and Cribari-Neto 
2010), which performs maximum likelihood estimation for the parameters of each variable. This second model should better capture any nonlinearity.

Table 1 shows the result of both linear and beta regressions for our domestic variables (Model 1), our systemic variables (Model 2), and all variables (Model 3).

Table 1: Statistical analysis.

\begin{tabular}{|c|c|c|c|c|c|c|}
\hline & \multicolumn{2}{|c|}{ Domestic variables } & \multicolumn{2}{|c|}{ Systemic variables } & \multicolumn{2}{|c|}{ Final models } \\
\hline & $\begin{array}{l}\text { Model } 1 \\
\text { (Linear) }\end{array}$ & $\begin{array}{l}\text { Model } 1 \\
(\beta)\end{array}$ & $\begin{array}{l}\text { Model } 2 \\
\text { (Linear) }\end{array}$ & $\begin{array}{l}\text { Model } 2 \\
(\beta)\end{array}$ & $\begin{array}{l}\text { Model } 3 \\
\text { (Linear) }\end{array}$ & $\begin{array}{c}\text { Model } 3 \\
(\beta)\end{array}$ \\
\hline \multirow[t]{2}{*}{$\Delta$ Presidential ideology $(\mathrm{H} 1)$} & $0.134^{* * *}$ & $0.803^{* * *}$ & & & $0.133^{* * *}$ & $0.821^{* * *}$ \\
\hline & $(0.011)$ & $(0.073)$ & & & $(0.011)$ & $(0.076)$ \\
\hline \multirow[t]{2}{*}{ Presidential power $(\mathrm{H} 2)$} & -0.00805 & 0.0181 & & & -0.0051 & 0.0321 \\
\hline & -0.00928 & -0.0291 & & & -0.00906 & -0.0286 \\
\hline \multirow[t]{2}{*}{ Presidential instability (H3) } & $0.0787^{*}$ & $0.446^{*}$ & & & 0.0661 & 0.223 \\
\hline & -0.0304 & -0.202 & & & -0.0341 & -0.212 \\
\hline \multirow{2}{*}{$\begin{array}{l}\text { Weak presidential } \\
\text { bureaucracy }(\mathrm{H} 4)\end{array}$} & $0.365^{* *}$ & -0.417 & & & $0.339^{* *}$ & -0.426 \\
\hline & -0.116 & -0.391 & & & -0.104 & -0.393 \\
\hline \multirow{2}{*}{$\begin{array}{l}\Delta \text { Incumbent party ideology } \\
\text { (H5) }\end{array}$} & 0.0155 & 0.0306 & & & 0.0103 & -0.017 \\
\hline & $(0.011)$ & $(0.074)$ & & & $(0.011)$ & $(0.076)$ \\
\hline \multirow[t]{2}{*}{ Electoral volatility (H6) } & 0.000 & 0.000 & & & 0.001 & 0.002 \\
\hline & $(0.000)$ & $(0.005)$ & & & $(0.000)$ & $(0.005)$ \\
\hline \multirow[t]{2}{*}{ Democratic scores (H7) } & -0.001 & 0.021 & & & 0.001 & 0.029 \\
\hline & $(0.007)$ & $(0.045)$ & & & $(0.007)$ & $(0.046)$ \\
\hline \multirow[t]{2}{*}{ Radicalism (H8) } & 0.003 & 0.357 & & & -0.010 & 0.131 \\
\hline & $(0.068)$ & -0.325 & & & $(0.060)$ & $(0.324)$ \\
\hline \multirow[t]{2}{*}{ End of Cold War (H9) } & & & 0.067 & 0.327 & 0.042 & 0.306 \\
\hline & & & $(0.039)$ & $(0.250)$ & $(0.023)$ & $(0.199)$ \\
\hline \multirow[t]{2}{*}{ Attacks of 9/11 (H10) } & & & -0.020 & -0.293 & 0.003 & -0.049 \\
\hline & & & $(0.041)$ & $(0.245)$ & $(0.025)$ & $(0.198)$ \\
\hline \multirow[t]{2}{*}{ Economic growth (H11) } & & & $-0.009^{*}$ & $-0.050^{*}$ & -0.0015 & $-0.0354^{*}$ \\
\hline & & & $(0.003)$ & $(0.020)$ & $(0.002)$ & $(0.018)$ \\
\hline \multirow[t]{2}{*}{ Influence of the US (H12) } & & & -41.48 & -259 & -19.47 & -50.98 \\
\hline & & & $(31.50)$ & (170.9) & $(22.23)$ & (147.4) \\
\hline \multirow[t]{2}{*}{ Influence of China (H13) } & & & 56.61 & 261 & -12.38 & -328.5 \\
\hline & & & $(36.85)$ & (366.6) & $(43.72)$ & $(381.2)$ \\
\hline Country fixed effects & YES & NO & YES & NO & YES & NO \\
\hline Robust SE & YES & NO & YES & NO & YES & NO \\
\hline \multirow[t]{2}{*}{ Constant } & -0.0707 & -3.215 & 0.194 & -1.405 & -0.119 & -3.400 \\
\hline & $(0.188)$ & $(0.865)$ & $(0.017)$ & $(0.142)$ & (0.169) & $(0.854)$ \\
\hline $\mathrm{R}^{2}$ & 0.414 & & 0.139 & & 0.463 & \\
\hline \multirow[t]{2}{*}{ Log-likelihood } & & 2.481 & & 1.664 & & 2.587 \\
\hline & & $(0.133)$ & & $(0.132)$ & & $(0.134)$ \\
\hline Observations & 121 & 118 & 121 & 118 & 121 & 118 \\
\hline
\end{tabular}

Standard errors in parentheses.

Statistical significance: ${ }^{*} p<0.05 ;{ }^{* *} p<0.01 ;{ }^{* * *} p<0.001$. 


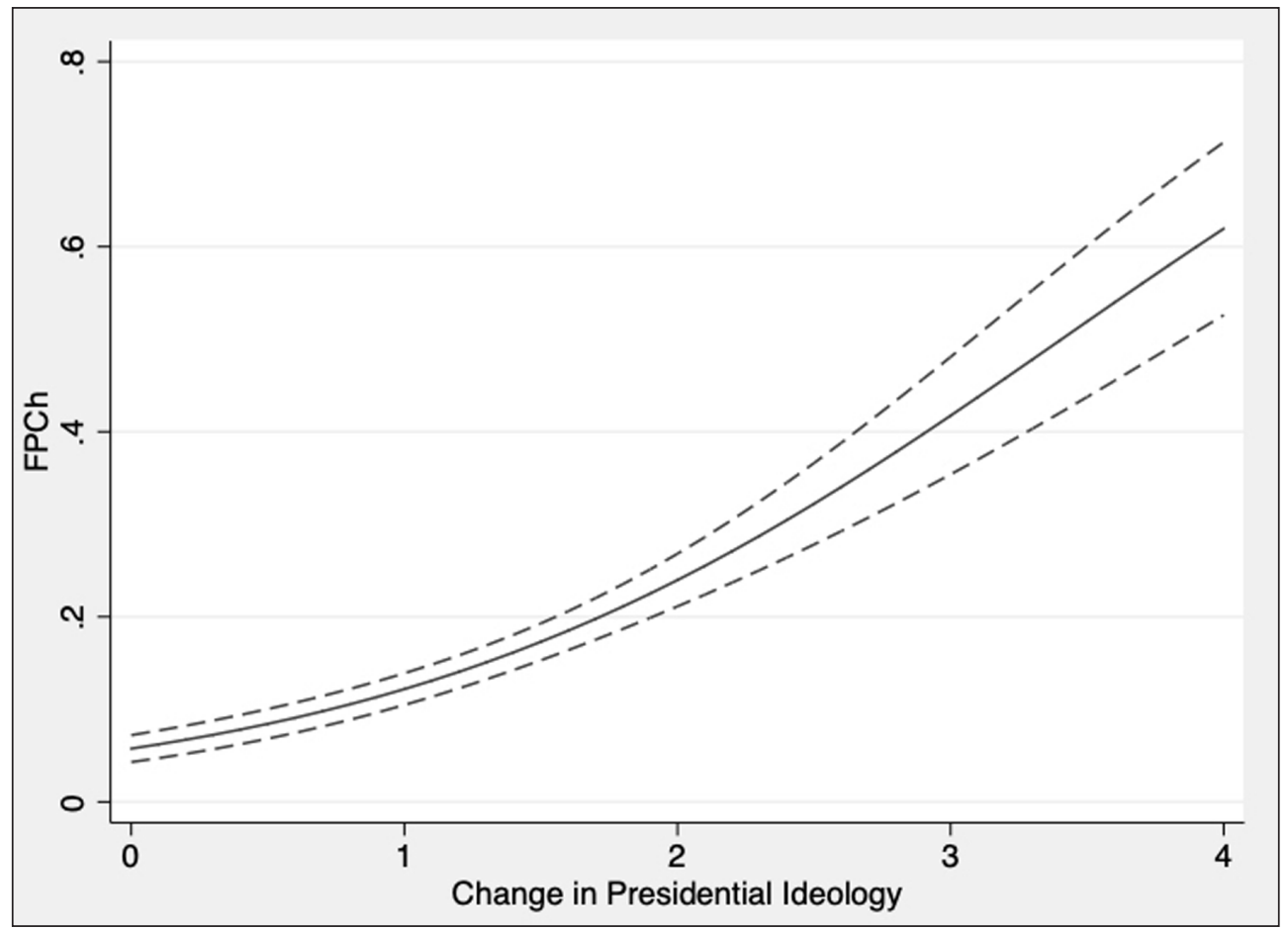

Figure 3: Maximum likelihood prediction with 95 percent confidence intervals.

\section{Findings}

Looking at the $\mathrm{R}^{2}$ statistics in the linear models reveals that most of FPCh is explained by domestic variables alone. Although economic growth seems to have had a significant and nontrivial effect on foreign policy realignment, it is not clear that this is per se a systemic variable, and international variables account for only a small part of the overall variation in FPCh. However, it is interesting that the effect of economic growth is in line with our expectations, with more growth affecting FPCh negatively.

Among the domestic variables, the effect of ideological change at the level of the incumbent president is no doubt the most impressive one, both statistically and substantively. As we expect, presidential instability and weak bureaucracies also seem to be relatively powerful predictors of FPCh but are outshined by the effects of a change in the president's ideological persuasion.

Following the results of the linear specification of Model 3, the maximum change in presidential ideology observable in our sample-a value of roughly 4 in the 7-point scale-leads to the maximum observable change in FPCh-a value of 0.6 in the $0-1$ continuum. Figure 3 shows that the nonparametric models (in this case the beta specification of Model 3) almost exactly replicate these results.

Looking retrospectively at our data, we find this relation is not surprising. Our composite index of FPCh and change in presidential ideology correlate very highly $(0.8)$ in our sample. There is at least one interpretation of these results that is clear: presidents are very important in defining foreign policy in Latin America. Although we already knew this was the case, the finding serves as corroboration and a reminder that presidents often follow their preferences in foreign policy across the board, despite variation in presidential power from country to country. Only their bureaucracies and economic growth seem to have a stabilizing effect, but the whims of presidents can also be exacerbated in contexts of presidential crises.

In another alternative interpretation, radical ideological change and the positive effect of presidential crises could be capturing the effect of intra-elite struggle (Schweller 2006; Schenoni 2017). It might be that big changes in presidential ideology happen in countries where this phenomenon is actually present. Take Argentina. Malamud $(2011,88)$ observes that in the last decades the foreign policies "flowing out of the Casa Rosada have been at least as many as the presidents themselves." Foreign-policy reorientation, he continues, "have occurred in the wake of both regime change and administration change." Based on these observations, Malamud $(2011,87)$ offers a tentative explanation of Argentina's volatile foreign policy: "foreign policy may not be internally coherent, either ideologically or pragmatically, but rather expresses domestic struggles, reflex actions and even personal moods." Thus, he adds, "foreign-policy subordination to short-term domestic concerns [cortoplacismo interno] could explain a great deal of the Argentina puzzle." This interpretation brings us back to our qualitative insight about the hierarchy of foreign policy change. Chile, Colombia, and Uruguay, whose foreign policies have been relatively consistent in recent decades, have 
also been less prone to ideological shifts. Conversely, examples of erratic and bombastic foreign policies, like those of Bolivia, Ecuador, and Venezuela, were also systematically unstable throughout the period. In sum, change in presidential ideology could be reflecting historical, even country-specific, trends despite the statistical tools we have applied to control for those.

\section{Conclusions}

In this article we have provided a first approximation to an examination of foreign policy change in Latin America. We identified the three dimensions that largely define foreign policy orientation in the region. We then aggregated them into a single index and calculated the change between different administrations. We did that for nineteen Latin American countries between 1980 and 2014, but our procedure could be replicated to analyze foreign policy change in other time periods and regions as well.

After providing several descriptive statistics of foreign policy change in Latin America, we switched to an explanatory focus. Having answered the question of what foreign policy change is, we asked how one could predict it. The results we obtained using both linear and nonparametric specifications were very clear and consistent: presidential preferences matter the most. Putting it simply, a change in the preferences of the president produces a change in foreign policy that is almost equivalent in magnitude, when all other theoretically relevant factors are set to their means. Three conclusions arise from these findings. First, presidents virtually define foreign policy change in Latin America. Second, it is the change in their ideology-not in their power-that affects foreign policy change. Third, presidents can be limited by strong bureaucracies but can also be whimsical when their power is at stake in the event of presidential crises.

The argument pursued here is not meant to exclude the international system. We do not make the strong assertion that transnational pressures have no influence on Latin America's foreign policy twists and turns; instead our empirical strategy has been to take a tighter focus on the influence of domestic politics. Similarly, our findings do not preclude the possibility that other domestic variables might affect foreign policy change; in fact we understand that most of the mechanisms we try to uncover still remain obscure. The main contribution of this work may be to conceptualize foreign policy change and set the stage for a potentially fruitful debate. Future research could and should revise our findings by expanding the set of hypotheses we have considered and delving into the nuances of our key findings.

\section{Additonal Files}

The additional files for this article can be found as follows:

Database on Presidents and Foreign Policy in Latin America. DOI: https://doi.org/10.25222/ larr.380.s1

- Do File Appendix. DOI: https://doi.org/10.25222/larr.380.s2

- Do File Appendix II. DOI: https://doi.org/10.25222/larr.380.s3

\section{Author Information}

Federico Merke is professor of international relations at Universidad de San Andrés and researcher at the National Scientific and Technical Research Council, Buenos Aires, Argentina.

Diego Reynoso is a researcher at the National Scientific and Technical Research Council and professor at Universidad de San Andrés, Buenos Aires, Argentina.

Luis Schenoni is a postdoctoral researcher at the University of Konstanz, Germany, and affiliated professor at Centro de Investigación y Docencia Económicas (CIDE), Mexico.

\section{References}

Abdi, Hervé, and Lynne J. Williams. 2010. "Principal Component Analysis." Wiley Interdisciplinary Reviews: Computational Statistics 2 (4): 433-459. DOI: https://doi.org/10.1002/wics.101

Alden, Chris, and Amnon Aran. 2017. Foreign Policy Analysis. London: Routledge. DOI: https:// doi.org/10.4324/9781315442488

Allison, Graham, and Philip Zelikow. 1999. Essence of Decision: Explaining the Cuban Missile Crisis. 2nd ed. Reading, MA: Longman.

Amorim Neto, Octavio. 2012. De Dutra a Lula: A condução e os determinantes da política externa brasileira. Rio de Janeiro: Elsevier. 
Amorim Neto, Octavio, and Andrés Malamud. 2015. "What Determines Foreign Policy in Latin America? Systemic versus Domestic Factors in Argentina, Brazil, and Mexico." Latin American Politics and Society 57 (4): 1-27. DOI: https://doi.org/10.1111/j.1548-2456.2015.00286.x

Atkins, Pope. 1999. Latin America and the Caribbean in the International System. Boulder: Westview Press.

Barbieri, Katherine, Omar M. G. Keshk, and Brian Pollins. 2009. "Trading Data: Evaluating Our Assumptions and Coding Rules." Conflict Management and Peace Science 26 (5): 471-491. DOI: https:// doi.org/10.1177/0738894209343887

Beck, Nathaniel, and Jonathan Katz. 1995. "What to Do (and Not to Do) with Time-Series Cross-Section Data." American Political Science Review 89 (3): 634-647. DOI: https://doi.org/10.2307/2082979

Belem Lopes, Dawisson, Carlos A. Pimenta de Faria, and Manoel Santos. 2016. "Foreign Policy Analysis in Latin American Democracies: The Case for a Research Protocol." Revista Brasileira de Política Internacional 59 (1). DOI: https://doi.org/10.1590/0034-7329201600106

Bergsten, Fred. 2002. "A Renaissance for U.S. Trade Policy?" Foreign Affairs 81 (6): 86-98. DOI: https:// doi.org/10.2307/20033346

Bertucci, Mariano. 2013. "Scholarly Research on U.S.-Latin American Relations: Where Does the Field Stand?" Latin American Politics and Society 55 (4): 119-142. DOI: https://doi.org/10.1111/j.15482456.2013.00211.x

Blavoukos, Spyros, and Dimitris Bourantonis. 2014. "Identifying Parameters of Foreign Policy Change: An Eclectic Approach." Cooperation and Conflict 49 (4): 483-500. DOI: https:// doi.org/10.1177/0010836713517568

Bollen, Kenneth A., and Pamela Paxton. 2000. "Subjective Measures of Liberal Democracy." Comparative Political Studies 33 (1): 58-86. DOI: https://doi.org/10.1177/0010414000033001003

Bouzas, Roberto. 2000. "Trade and Investment Issues in the Americas: A Look Ahead." In The Future of InterAmerican Relations, edited by Jorge Domínguez, 197-214. New York: Routledge.

Briceño Ruiz, José. 2012. "Raúl Prebisch e a contribuição latino americana para a teoria das relações internacionais." In Teóricos das relações internacionais, edited by Marcos Costa Lima, Rafael Villa, Rossana R. Reis, and Marcelo A. Madeiros, 177-219. São Paulo: Hucitec.

Budge, Ian. 2000. "Expert Judgements of Party Policy Positions: Uses and Limitations in Political Research." European Journal of Political Research 37: 103-113. DOI: https://doi.org/10.1111/1475-6765.00506

Bueno de Mesquita, Bruce, Alastair Smith, Randolph M. Siverson, and James D. Morrow. 2003. The Logic of Political Survival. Cambridge, MA: MIT Press. DOI: https://doi.org/10.7551/mitpress/4292.001.0001

Burges, Sean, and Fabricio Chagas Bastos. 2017. "The Importance of Presidential Leadership for Brazilian Foreign Policy." Policy Studies 38 (3): 277-290. DOI: https://doi.org/10.1080/01442872.2017.1290228

Carlsnaes, Walter. 1992. "The Agency-Structure Debate Problem in Foreign Policy Analysis." International Studies Quarterly 36: 245-270. DOI: https://doi.org/10.2307/2600772

Carothers, Thomas. 1993. In the Name of Democracy: U.S. Policy Toward Latin America. Berkeley: University of California Press.

Close, David. 2011. "Nicaragua's Pragmatic Ideologues." In Latin American Foreign Policies: Between Ideology and Pragmatism, edited by Gian Luca Gardini and Paul Lambert, 197-212. London: Palgrave Macmillan. DOI: https://doi.org/10.1057/9780230118270_12

Collier, David, and Steven Levitsky. 1997. "Democracy with Adjectives: Conceptual Innovation in Comparative Research." World Politics 49: 430-451. DOI: https://doi.org/10.1353/wp.1997.0009

Da Faria, Carlos, Dawisson Lopes, and Guilherme Casarões. 2013. "Itamaraty on the Move: Institutional and Political Change in Brazilian Foreign Service under Lula d a Silva's Presidency (2003-2010)." Bulletin of Latin American Research 32 (4): 468-482. DOI: https://doi.org/10.1111/blar.12067

Emerson, Guy. 2015. "Strong Presidentialism and the Limits of Foreign Policy Success: Explaining Cooperation Between Brazil and Venezuela." International Studies Perspectives 16 (4): 484-499. DOI: https:// doi.org/10.1111/insp.12071

Escudé, Carlos. 1992. Realismo periférico. Buenos Aires: Planeta.

Feinberg, Richard. 2002. "Regionalism and Domestic Politics: U.S.-Latin American Trade Policy in the Bush Era." Latin American Politics and Society 44 (4): 127-152. DOI: https:// doi.org/10.1111/j.1548-2456.2002.tb00225.x

Fernández, Damián. 2003. “Cuba: Talking Big, Acting Bigger." In Latin American and Caribbean Foreign Policy, edited by Frank O. Mora and Jeanne A. K. Hey, 84-103. Lanham, MD: Rowman and Littlefield.

Fernandois, Joaquín. 2011. "Pragmatism, Ideology, and Tradition in Chilean Foreign Policy Since 1990." In Latin American Foreign Policies: Between Ideology and Pragmatism, edited by Gian Luca Gardini and Paul Lambert, 35-52. London: Palgrave Macmillan. DOI: https://doi.org/10.1057/9780230118270_3 
Ferrari, Silvia L., and Francisco Cribari-Neto. 2010. "Beta Regression for Modelling Rates and Proportions." Journal of Applied Statistics 31 (7): 799-815. DOI: https://doi.org/10.1080/0266476042000214501

Gardini, Gian Luca, and Paul Lambert, eds. 2011. Latin American Foreign Policies: Between Ideology and Pragmatism. London: Palgrave. DOI: https://doi.org/10.1057/9780230118270

Garrison, Jean. 2006. "From Stop to Go in Foreign Policy." International Studies Review 8 (2): 291-293. DOI: https://doi.org/10.1111/j.1521-9488.2006.00577.x

Giacalone, Rita. 2012. "Latin American Foreign Policy Analysis: External Influences and Internal Circumstances." Foreign Policy Analysis 8 (4): 335-354. DOI: https://doi.org/10.1111/j.17438594.2011.00176.x

Goertz, Gary. 2006. Social Science Concepts: A User's Guide. Princeton, NJ: Princeton University Press. DOI: https://doi.org/10.1515/9781400842995

Goertz, Gary. 2017. Multimethod Research, Causal Mechanisms, and Case Studies, Princeton, NJ: Princeton University Press. DOI: https://doi.org/10.1515/9781400888115

Goldmann, Kjell. 1988. Change and Stability in the International System. New York: Harvester Wheatsheaf.

Gómez Mera, Laura. 2009. "Domestic Constraints on Regional Cooperation: Explaining Trade Conflict in MERCOSUR." Review of International Political Economy 16 (5): 746-777. DOI: https://doi.org/ $10.1080 / 09692290802454216$

Grugel, Jean, and Pia Riggirozzi. 2012. "Post-neoliberalism in Latin America: Rebuilding and Reclaiming the State after Crisis." Development and Change 43 (1): 1-21. DOI: https://doi.org/10.1111/j.14677660.2011.01746.x

Gustavsson, Jakob. 1999. "How Should We Study Foreign Policy Change?" Cooperation and Conflict 34 (1): 73-95. DOI: https://doi.org/10.1177/00108369921961780

Hey, Jeanne A. K. 1997. "Three Building Blocks of a Theory of Latin American Foreign Policy." Third World Quarterly 18 (4): 631-657. DOI: https://doi.org/10.1080/01436599714687

Jaguaribe, Hélio. 1985. El nuevo escenario internacional: Autonomía periférica y hegemonía del centro. Mexico City: Fondo de Cultura Económica.

Jenne, Nicole, Luis Schenoni, and Francisco Urdinez. 2017. "Of Words and Deeds: Latin American Declaratory Regionalism, 1994-2014." Cambridge Review of International Affairs 30 (2-3): 195-215. DOI: https:// doi.org/10.1080/09557571.2017.1383358

Kryzanek, M. 1990. US-Latin American Relations. New York: Praeger.

Lake, David A. 2011. "Why 'isms' Are Evil: Theory, Epistemology, and Academic Sects as Impediments to Understanding and Progress." International Studies Quarterly 55 (2): 465-480. DOI: https://doi .org/10.1111/j.1468-2478.2011.00661.x

Levitsky, Steven, and Lucan Way. 2010. Competitive Authoritarianism: Hybrid Regimes after the Cold War. New York: Cambridge University Press. DOI: https://doi.org/10.1017/CBO9780511781353

Lima, Maria Regina Soares, and Fabiano Santos. 2001. "O congresso e a política exterior." Lua Nova 52: $121-150$.

Llanos, Mariana, and Leiv Marsteintredet, eds. 2010. Presidential Breakdowns in Latin America: Causes and Outcomes of Executive Instability in Developing Democracies. New York: Palgrave Macmillan.

Long, Tom. 2015. Latin America Confronts the United Sates. New York: Cambridge University Press. DOI: https://doi.org/10.1017/CBO9781316343890

Mahoney, James. 2010. Colonialism and Postcolonial Development: Spanish America in Comparative Perspective. New York: Cambridge University Press. DOI: https://doi.org/10.1017/CBO9780511750328

Mainwaring, Scott. 2017. Party Systems in Latin America: Institutionalization, Decay, and Collapse. New York: Cambridge University Press. DOI: https://doi.org/10.1017/9781316798553

Mainwaring, Scott, and Aníbal Pérez-Liñán. 2013. "Democratic Survival in Latin America." Journal of Democracy 24 (2): 123-137. DOI: https://doi.org/10.1353/jod.2013.0037

Malamud, Andrés. 2005. "Presidential Diplomacy and the Institutional Underpinnings of Mercosur: An Empirical Examination." Latin American Research Review 40 (1): 138-164. DOI: https://doi.org/10.1353/ lar.2005.0004

Malamud, Andrés. 2011. "Argentine Foreign Policy under the Kirchners: Ideological, Pragmatic, or Simply Peronist?" In Latin American Foreign Policies: Between Ideology and Pragmatism, edited by Gian Luca Gardini and Paul Lambert, 87-102. London: Palgrave Macmillan. DOI: https:// doi.org/10.1057/9780230118270_6

Malamud, Andrés. 2014. "Presidentialist Decision Making in Latin American Foreign Policy: Examples from Regional Integration Processes." In Routledge Handbook of Latin America in the World, edited by Jorge Domínguez and Ana Covarrubias, 112-123. London: Routledge. 
Margheritis, Ana. 2010. Argentina's Foreign Policy: Domestic Politics and Democracy Promotion in the Americas. Boulder, CO: Lynne Rienner.

Mattes, Michaela, Brett Ashley Leeds, and Naoko Matsumura. 2016. "Measuring Change in Source of Leader Support: The CHISOLS Dataset." Journal of Peace Research 53 (2): 259-267. DOI: https:// doi.org/10.1177/0022343315625760

Mearsheimer, John. 2001. The Tragedy of Great Power Politics. New York: W. W. Norton.

Merke, Federico, and Diego Reynoso. 2016. "Dimensiones de política exterior en América Latina según juicio de expertos." Estudios Internacionales 185: 107-131.

Milner, Helen V., and Dustin Tingley. 2016. Sailing the Water's Edge: The Domestic Politics of American Foreign Policy. Princeton, NJ: Princeton University Press. DOI: https://doi.org/10.1515/9781400873821

Mora, Frank O., and Jeanne A. K. Hey. 2003. Latin American and Caribbean Foreign Policy. Lanham, MD: Rowman and Littlefield.

Morales, Waltraud. 2003. "Bolivia: The Struggle for Autonomy." In Latin American and Caribbean Foreign Policy, edited by Frank O. Mora and Jeanne A. K. Hey, 228-242. Lanham, MD: Rowman and Littlefield.

Murillo, María Victoria, Virginia Oliveros, and Milan Vaishnav. 2011. "Economic Constraints and Presidential Agency." In The Resurgence of the Latin American Left, edited by Steven Levitsky and Kenneth M. Roberts, 52-70. Baltimore: Johns Hopkins University Press.

Pastor, Robert. 2001. Exiting the Whirlpool: U.S. Foreign Policy towards Latin America and the Caribbean. Boulder, CO: Westview Press.

Pastor, Robert, and Tom Long. 2010. "The Cold War and Its Aftermath:The Search for a Synthetic Interpretation of U.S. Foreign Policy." Latin American Research Review 45 (3): 261-273.

Pérez-Liñán, Aníbal. 2007. Presidential Impeachment and the New Political Instability in Latin America. Cambridge: Cambridge University Press. DOI: https://doi.org/10.1017/CBO9780511510335

Phillips, Nicola. 2003. "Hemispheric Integration and Subregionalism in the Americas." International Affairs 79 (2): 257-279. DOI: https://doi.org/10.1111/1468-2346.00311

Phillips, Nicola. 2004. The Southern Cone Model: The Political Economy of Regional Capitalist Development in Latin America. London: Routledge. DOI: https://doi.org/10.4324/9780203463338

Phillips, Nicola. 2014. "The Dynamics of Asymmetrical Development." In Routledge Handbook of Latin America in the World, edited by Jorge Domínguez and Ana Covarrubias, 85-96. New York: Routledge.

Puig, Juan Carlos. 1980. Doctrinas internacionales y autonomía latinoamericana. Caracas: Instituto de Altos Estudios de América Latina, Universidad Simón Bolívar.

Rivarola Puntigliano, Andrés. 2008. "Suspicious Minds: Recent Books on U.S.-Latin American Relations." Latin American Politics and Society 50 (4): 155-172. DOI: https://doi.org/10.1111/j.1548-2456.2008.00033.x

Robinson, William. 2008. Latin America and Global Capitalism. Baltimore: Johns Hopkins University Press.

Rosati, Jerel. 1994. "Cycles in Foreign Policy Restructuring: The Politics of Continuity and Change in U.S. Foreign Policy." In Foreign Policy Restructuring. How Governments Respond to Global Change, edited by Jerel Rosati, Joel Hagan, and Martin Sampson, 221-261. Columbia: University of South Carolina Press.

Russell, Roberto, and Juan Tokatlian. 2003. "From Antagonistic to Relational Autonomy: A Theoretical Reflection from the Southern Cone." Latin American Politics and Society 45 (1): 1-24. DOI: https:// doi.org/10.1111/j.1548-2456.2003.tb00230.x

Sanchez, Peter. 2003. "Panama: The Limits of Sovereignty." In Latin American and Caribbean Foreign Policy, edited by Frank O. Mora and Jeanne A. K. Hey, 63-83. Lanham, MD: Rowman and Littlefield.

Schedler, Andreas. 2012. "Judgment and Measurement in Political Science." Perspectives on Politics 10 (1): 21-36. DOI: https://doi.org/10.1017/S1537592711004889

Schenoni, Luis. 2017. "Subsystemic Unipolarities? Power Distribution and State Behaviour in South America and Southern Africa." Strategic Analysis 41 (1): 74-86. DOI: https://doi.org/10.1080/09700161.2016.12 49179

Schenoni, Luis, and Alejo F. Aztiria. 2014. "Actores domésticos y política exterior en Argentina y Brasil." Confines 10 (19): 113-142.

Schenoni, Luis, and Carlos Escudé. 2016. "Peripheral Realism Revisited." Revista Brasileira de Política Internacional 59 (1): 1-18. DOI: https://doi.org/10.1590/0034-7329201600102

Schoultz, Lars. 1998. Beneath the United States: A History of U.S. Policy Toward Latin America. Cambridge, MA: Harvard University Press.

Schweller, Randall. 2006. "Unanswered Threats: Political Constraints on the Balance of Power." Princeton, NJ: Princeton University Press. 
Skidmore, David. 1994. "Explaining State Responses to International Change: The Structural Sources of Foreign Policy Rigidity and Change." In Foreign Policy Restructuring: How Governments Respond to Global Change, edited by Jerel Rosati and Joe Hagan, 43-61. Columbia: University of South Carolina Press.

Smith, Peter. 2000. Talons of the Eagle: Dynamics of U.S.-Latin American Relations. New York: Oxford University Press.

Soifer, Hillel D. 2015. State Building in Latin America. New York: Cambridge University Press. DOI: https:// doi.org/10.1017/CBO9781316257289

Tsebelis, George. 2002. Veto Players: How Political Institutions Work. Princeton, NJ: Princeton University Press. DOI: https://doi.org/10.1515/9781400831456

Tulchin, Joseph. 2016. Latin America in International Politics: Challenging US Hegemony. Boulder, CO: Lynne Rienner.

Tussie, Diana. 2009. "Latin America: Contrasting Motivations for Regional Projects." Review of International Studies 35 (1): 169-188. DOI: https://doi.org/10.1017/S026021050900847X

Urdinez, Francisco, Fernando Mouron, Luis Schenoni, and Amancio Oliveira. 2016. "Chinese Economic Statecraft and US Hegemony in Latin America: An Empirical Analysis, 2003-2014." Latin American Politics and Society 58 (4): 3-30. DOI: https://doi.org/10.1111/laps.12000

Varieties of Democracy Project. 2017. "V-Dem [Country-Year/Country-Date] Dataset v7.1." https://www.vdem.net/en/data/archive/previous-data/data-version-7-1/.

Weeks, Gregory. 2009. "Recent Works on U.S.-Latin American Relations." Latin American Research Review 44 (1): 247-256. DOI: https://doi.org/10.1353/lar.0.0064

Welch, David. 2005. Painful Choices: A Theory of Foreign Policy Change. Princeton, NJ: Princeton University Press. DOI: https://doi.org/10.1515/9781400840748

Williams, Mark Eric. 2011. Understanding U.S.-Latin American Relations: Theory and History. New York: Routledge. DOI: https://doi.org/10.4324/9780203805107

How to cite this article: Merke, Federico, Diego Reynoso, and Luis Leandro Schenoni. 2020. Foreign Policy Change in Latin America: Exploring a Middle-Range Concept. Latin American Research Review 55(3), pp. 413-429. DOI: https:// doi.org/10.25222/larr.380

Submitted: 13 November 2017

Accepted: 11 June 2018

Published: 08 September 2020

Copyright: () 2020 The Author(s). This is an open-access article distributed under the terms of the Creative Commons Attribution 4.0 International License (CC-BY 4.0), which permits unrestricted use, distribution, and reproduction in any medium, provided the original author and source are credited. See http://creativecommons.org/ licenses/by/4.0\%. 